\title{
Determinants of Exports in a Small and Vulnerable Economy: Fiji Islands-A Disaggregated Analysis
}

\author{
Ronal Chand ${ }^{1} \cdot$ Rup Singh ${ }^{1} \cdot$ Sumeet Lal $^{1} \cdot$ Nilesh Chand $^{1,2}$. \\ Devendra Kumar Jain ${ }^{1}$
}

Accepted: 18 December 2021 / Published online: 11 February 2022

(c) European Association of Development Research and Training Institutes (EADI) 2022

\begin{abstract}
The previous studies of exports performance in Fiji were carried out at the aggregate level. We conduct a disaggregated analysis of exports of three major products, namely, sugar, tourism, and gold. This analysis is useful for developing sector-based export promotion policies. The long run as well as dynamic export demand functions are estimated at the aggregate and disaggregate levels. The results identify a number of factors such as trading partner income, relative prices, productivity shocks, natural disasters, political disturbances, and the exchange rate that affect the export demand for sugar, tourism, and gold, though not in the same way. For instance, tourism and sugar enjoy the highest income elasticity. Sugar export is adversely affected by natural calamities and political upheavals. The political upheavals also affect tourism adversely in Fiji. The exchange rate affects the export of sugar more than others. The idea that devaluation will promote exports in Fiji needs careful investigation because results show that this will happen with a high cost, i.e. 5\% nominal devaluation will be required to increase real exports by $1 \%$.
\end{abstract}

Keywords Determinants of exports - Export promotion policies $\cdot$ Elasticities of exports $\cdot$ Small and vulnerable economies $\cdot$ Fiji

Devendra Kumar Jain

dkumar54@gmail.com

Ronal Chand

ronal.chand@usp.ac.fj

Rup Singh

rup.singh@usp.ac.fj

Sumeet Lal

sumeet.lal@usp.ac.fj

Nilesh Chand

nitinair767@gmail.com

1 School of Accounting, Finance and Economics, The University of the South Pacific, Suva, Fiji

2 Fijian Competition and Consumer Commission, Suva, Fiji 


\section{Résumé}

Les études précédentes sur la performance des exportations aux Fidji ont été réalisées au niveau global. Nous effectuons une analyse désagrégée des exportations de trois produits principaux, à savoir le sucre, le tourisme et l'or. Cette analyse est utile pour développer des politiques sectorielles de promotion des exportations. Nous estimons au niveau global et au niveau désagrégé des projections sur le long terme, ainsi que des fonctions dynamiques de demande d'exportation. Les résultats identifient un certain nombre de facteurs, tels que le revenu des partenaires commerciaux, les prix relatifs, les chocs de productivité, les catastrophes naturelles, les troubles politiques et les variations du taux de change, qui affectent la demande d'exportation pour le sucre, le tourisme et l'or, bien que l'impact soit différent. Par exemple, le tourisme et le sucre bénéficient de l'élasticité du revenu la plus élevée. L'exportation de sucre est affectée par les catastrophes naturelles et les bouleversements politiques. Les bouleversements politiques affectent également le tourisme dans les îles Fidji. Les variations du taux de change affectent l'exportation de sucre plus que les autres produits. Il faut soigneusement étudier l'idée selon laquelle, aux Fidji, la dévaluation monétaire va favoriser les exportations, car les résultats montrent que cela ne se produira qu'avec un coût élevé, c'est-à-dire qu'une dévaluation nominale de $5 \%$ sera nécessaire pour augmenter les exportations réelles de $1 \%$.

JEL Classification $\mathrm{A} 12 \cdot \mathrm{B} 13 \cdot \mathrm{B} 22 \cdot \mathrm{B} 40$

\section{Introduction}

Fiji is a Small and Vulnerable Economy (SVE) ${ }^{1}$ in the pacific region. It is a member of the World Trade Organization (WTO) and is also a signatory to most regional trade agreements such as PICTA (with regional countries), PACER-plus (regional, including Australia and New Zealand), the MSG (with Melanesian group of countries in the region), and Investment Fiji (2020a). Additionally, Fiji benefits from specific Economic Partnership Agreements (EPAs) with the UK, enjoy duty and quotafree access to the US market under the GATT arrangement (WTO 2020) and has recently finalised trade agreements with China and other Asian Economies under the Look North Trade Policy Framework (ADB 2020). These as well as Fiji's trade competitiveness determine its trade strategy. Fiji continues to benefit from the WTO's

\footnotetext{
1 We characterise SVEs as economies with low population (below 1 million), constrained with technology, natural and financial resources and those which depend on international support and/or on other exogenous factors such as worker remittances. Such economies are highly vulnerable to trade, climatic, and macroeconomic shocks without having adequate capacity to mitigate these challenges. WTO members recognise SVE, and its definition matches the criteria. Here are some definitional elements of SVE: "Small, vulnerable economies (SVEs) are those WTO members that account for only a small fraction of world trade. They are particularly vulnerable to economic uncertainties and environmental shocks 1 . WTO members recognize that SVEs, while not forming an official sub-category of members, face certain risks and agreed in 2002 on a Work Program on SVEs in accordance with the Doha Declaration".

(https://www.wto.org/english/thewto_e/minist_e/min11_e/brief_svc_e.htm).
} 
Aid-for-Trade initiative specially designed by the WTO for the SVEs (Investment Fiji 2020a). In addition, it receives support from the European Union (EU) for sugar and organic production (International Trade Centre 2020) following the expiry of the LOME Convention in February 2000.

However, apart from the current COVID-19 crisis which has greatly disturbed global connectivity and supply chains, there are other severe constraints that continue to undermine Fiji's trade and economic growth prospects. These constraints can be grouped into four categories: structural (low trade competitiveness, unproductive domestic industries, and limited scale-effects), connectivity (distance from major markets, high cost of trade, inconsistency of supply, and limited market access), natural (land availability and ownership, and vulnerability to climate events), and capacity (technology, innovations for trade creation, and finance). These have been discussed in Chand et al. (2020), FAO (2017), Tisdell (2014) and Armstrong and Read (2006).

In response to these constraints, the government has continued to promote local industries through strategic funding, international marketing, tax concessions, duty exceptions on raw materials, protection of selected domestic industries (MOE 2020), and export finance facilities (Reserve Bank of Fiji 2020). Apart from foreign aid and migrant remittances, trade in domestic exports (commodities and tourism) remains important for Fiji.

The nature of trade promotion policies, changes in trading partner income, and movements in relative price are known to influence the export performance. The market dynamics are highly unpredictable and uncontrollable in SVEs. It is therefore important to identify the key determinants of aggregate exports and that of its major components. This will help develop sector-based export promotion policies. This paper, therefore, examines the determinants of Fiji's major exports (tourism, sugar, and gold), which constitute $66 \%$ of total domestic exports. All the existing studies of exports in Fiji are conducted at the aggregate level (Prasad 2000; Rao and Singh 2007; Sami 2020). By conducting the analysis of exports performance at a disaggregate level, this paper fills up the gap in the Fijian trade literature.

The paper is organised as follows. In "Trade Strategy of Fiji" section, we briefly discuss the existing trade policy of Fiji. A review of literature on the studies of export performance is presented in "Studies of Export Performance: A Brief Survey" section. "Trends in Fiji Exports" section discusses trends in the growth of exports in Fiji. "Framework" section discusses the modelling framework which forms the basis for empirical exercise. "Data, Estimation, and Results" section discusses the data and empirical results, and the final "Conclusions" section brings together the conclusions.

\section{Trade Strategy of Fiji}

Fiji's trade strategy is guided by the government's vision to adopt key trade policies of the Asian countries (ADB 2020). As rightly argued in World Bank (1993) and Krugman (1994), the newly industrialised countries (Hong Kong, Singapore, South Korea, and Taiwan) sustained phenomenal rates of export-led growth. Domestic 
exports, together with other strategic variables such as financial market development, human capital, private investment, and government policy are important determinants of growth in broader Asia, Singh (2015). However, in order to promote trade-based growth in Fiji, the issues that relate to trade creation and facilitation are important (ADB 2018). As such, these have been influential components of trade policy in Fiji. Moreover, Fiji's increased integration into the global value chains to connect with major exporters and markets could be highly fruitful. This is because participation in the value chain enables access to a large customer base, along with the prospects of learning from big firms while engaging and surviving in the ardently challenged sectors of the global market (ADB 2015).

Fiji's existing trade policy framework revolves around the spirit of free trade. However, there are provisions (as in the WTO's general agreement-GATT) to engage in trade restrictions for various strategic reasons. This is congruent to other advanced countries' trade policies (such as the USA, UK, and Australia). Investment Fiji (2020a) resorts to some form of protection of domestic industries. Fiji operates under the pegged exchange rate system and uses exchange rate policy to enhance export competitiveness and manage domestic inflation. A global event such as trade tensions between major economies, debt, and financial crises as well as oil or food price hikes have inversely affected Fiji's trade, Chand et al. (2020). The recent outbreak of COVID-19 has greatly impacted the trade flow and labour mobility, and these continue to depress productive capacity, requiring measures to protect local industries.

Exports stimulate the domestic economy if there is high external demand elasticity satisfying the Marshall-Lerner condition. This is, however, less noticeable in Fiji and many other SVEs. At this stage, it might be better to clarify that despite weak commodity exports, Fiji has been able to reduce the twin deficit in the last couple of years with a healthy foreign exchange reserves position. This has been a result of increased international incomes from remittances, tourism earnings, and official development assistance. The Reserve Bank of Fiji also undertakes policy measures through exchange rate adjustments, exchange control, and export finance facility, as the need arises. Externally, the WTO together with the World Bank has identified mechanisms to support the development of national productive capacities using the Aid-for-Trade arrangements to increase SVEs participation in the global value chain, in addition to the special and differential treatments extended by the WTO to all the SVEs.

\section{Studies of Export Performance: A Brief Survey}

There is a vast literature on the relationship between exports and economic growth in developing countries, see e.g. Michaely (1977), Balassa (1978), Krugman (1984), Chow (1987), Sharma et al. (1991), Giles and Williams (2000), Alam (2003), and Udoidern et al. (2017). There is a handful but influential studies of exports performance in small and vulnerable economies. The literature shows that the export performances of SVEs are determined by many factors. Fugazza (2004) elaborates that the determinants of exports comprise both external factors, which includes 
demand-side conditions, and internal factors, which includes supply-side conditions. More specifically, external factors include foreign income of the trading partner countries, and relative prices of the export goods, whereas the internal factors may consist of depreciation of country's currency, the domestic price of export good, domestic income, and domestic events affecting the supply of exportable goods.

Different studies have reported different elasticities of aggregate exports concerning the above-discussed variables. Reddy (1997) reports 0.76 as the income elasticity of exports and -0.78 as the relative price elasticity. In the study of Asafu-Adjaye (1999), the long-run income elasticity is found to be 1.4 and the relative price elasticity to be -0.2 , suggesting that Fiji's exports are a luxury for its trading partners.

Prasad (2000) reports a long-run income elasticity of 2.4 for aggregate exports. Narayan and Narayan (2004) report income elasticity in the range of 0.70 to 0.81 and price elasticity in the range of -1.30 to -1.49 . Rao and Singh (2007) argue that if one fails to include the exchange rate in trade equations, the income elasticity is over-estimated. ${ }^{2}$ They estimate a long-run income elasticity of unity and the relative price elasticity of slightly more than -1.25 . Kumar (2009) reports that the income elasticity of exports is 1.08 while the relative price elasticity is -0.83 for Fiji. More recently, Prakash and Maiti (2016) have found a positive and significant impact of exchange rate devaluation on Fiji's goods and services trade. The results presented in Sami (2020) suggest that temporary measures to increase sugar export earnings will mostly be ineffective because the export earnings will not revert to its equilibrium path and the impacts will be transmitted to other related variables and sectors.

While for Fiji, there is clear evidence of high income and slightly lower relative price elasticity for aggregate exports, none of the studies have obtained the elasticities of the components of exports. Our paper bridges this gap by analysing the aggregate as well as decompositions of major exports of Fiji. Such analysis could prove useful for Fiji's trade policy as well as for other SVEs who are exploring sector-specific trade policy.

\section{Trends in Fiji Exports}

During the last 40 years, sugar, tourism, and gold have dominated Fiji's total export even though trade policy has experienced a drastic change. In the 1970-1980 period, Fiji had an import substitution policy to protect the infant and ailing domestic industries. However, a series of natural disasters in the 1980s and the political crisis of $1987^{3}$ had a serious adverse impact on the sugar and tourism industries. In addition, while the rest of the world advanced towards trade openness and globalisation, new doors for export creation opened for Fiji. These developments got Fiji to re-orient its trade strategy to export promotion and the government set up tax-free zones, export funding, international marketing, and encouraging commodity exports

\footnotetext{
2 They found an over-estimation of the relative price elasticity of around 40-65\% for Fiji.

3 Two Political coups took place in 1987; the first was in May and second occurred in September.
} 
(fish, garments, textiles and footwear, water, and timber). Consequently, new trade agreements were endorsed around this time (Investment Fiji 2020a), which gave a real boost to Fiji's trade performance.

Among Fiji's major exports, sugar contributes 13\%, garment around 10\%, gold and lumber around $8 \%$, Fish $9 \%$, and other small sectors to $52 \%$ of total domestic exports of goods. Tourism dominates the services industry. Initially, while these industries grew remarkably, data show a sluggish growth of total domestic export of goods and services over the past 20 years (Fig. 1a). The downward trend has been attributed to structural problems facing Fiji's commodity exports (especially the sugar industry), the lack of investment, adverse weather conditions, and declining productivity (Narayan and Prasad 2003; Narayan and Narayan 2004; Raj and Chand 2017). It could also be due to a reduced drive to promote these industries further by adopting creative ideas in secondary production, getting private investors to advance creative destruction, and exploring new areas of exports. The 1990 and early 2000 period was more of a constitutional rift following the 1987 crisis, in which Fiji lost human capital, investment funds, and economic confidence from businesses. As the industry learned, exports have shown improvements, well below what could have been achieved (Gounder 2004).

Sugar has been the most influential industry of the 1980s in terms of employment, entrepreneurship, incomes, and livelihoods in Fiji (FAO 2017). In this period, sugar (and its by-products) was the largest foreign exchange earner. However, as the 1987 crisis unfolded, the performance of sugar slipped after the mid-1980s (Fig. 1c). Although trade agreements guaranteed the EU market preferential pricing, the industry died a natural death due to industrial and national political problems. Since then, this sector sustained poor performance. Commentators attributed the decline of the industry to the forced eviction of farmers due to expiry of land leases, poor supply of sugarcane due to low productivity, development of other less resource-intensive industries, and unfavourable weather and political conditions (Pacific Community 2017; Prasad and Tisdell 1996). In 2008, export earnings from sugar exports rose to US $\$ 136.7 \mathrm{~m}$ compared to US\$103.2 $\mathrm{m}$ in 2007 . This was mainly because of excess rainfall which hampered harvesting in Brazil and India, (largest producers) extending a global supply deficit that pushed up the world market price for sugar. However, in 2010, the earnings severely fell to US\$36.54 $\mathrm{m}$. This decline in earnings was caused mainly by frequent mill breakdowns, which restrained cane harvesting and delivery to the mill. In 2012, the earnings rose because of improvements in the efficiency of milling. This sector has been highly volatile in its economic performance, productivity, and trade. More recent estimates reveal that the industry contributes not more than 13\% to GDP (Reserve Bank of Fiji 2020). The forecast for 2021 is a significant decline in sugar and cane production following the TC Yasa (in late 2020), which destroyed sugarcane farms in Vanua Levu (Ministry of Sugar 2020).

Since mid-2000, the tourism industry is most significant in terms of its impact and contribution to Fiji's economy (except for 2020, due to COVID-19). The industry provides direct and indirect employment, contributes significantly to infrastructure development, foreign reserves, and GDP. Deo (2019) finds that it contributes over $40 \%$ to Fiji's labour force and around $60 \%$ to the GDP. In the last 20 years, visitor arrivals have increased significantly (Fig. 1b). Consequently, 

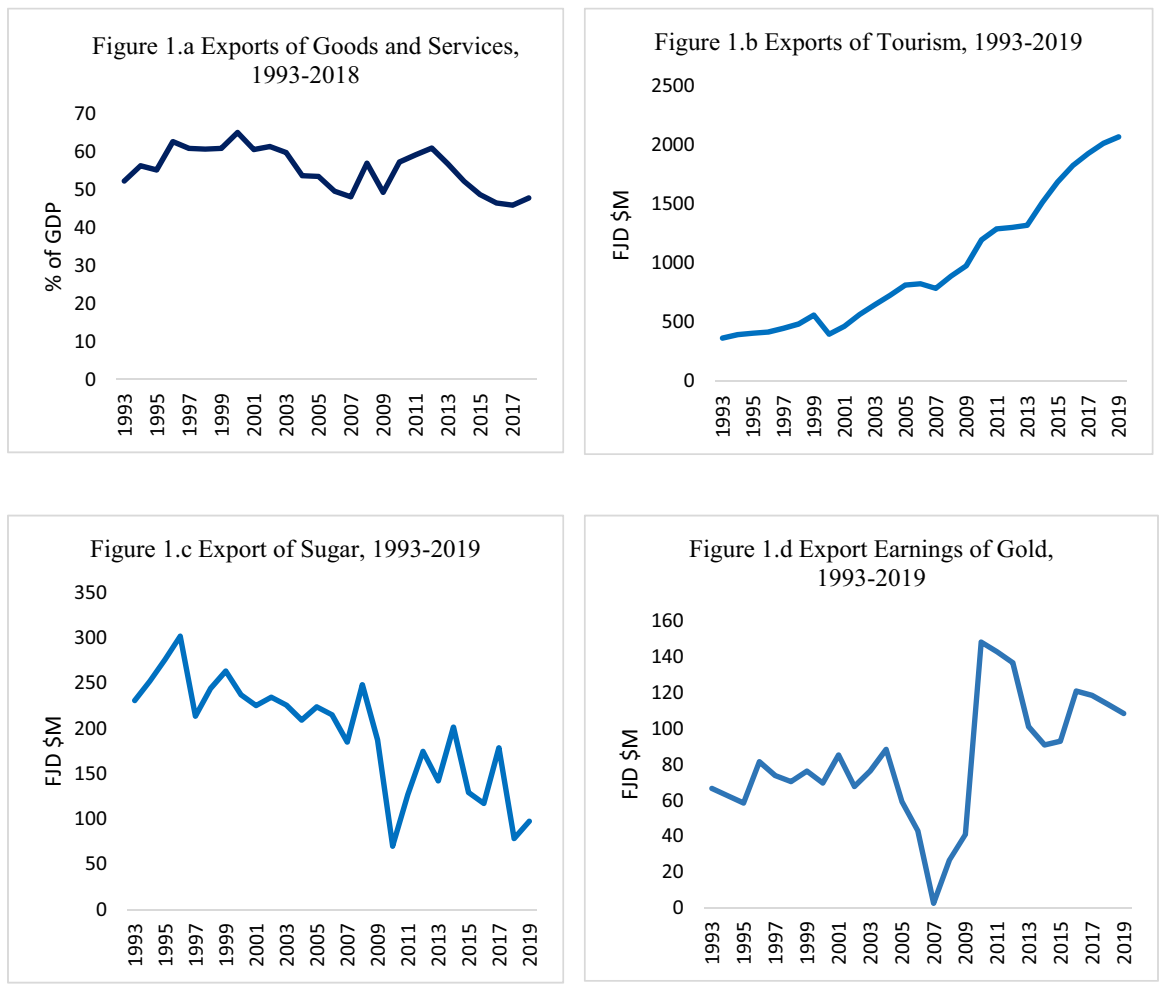

Fig. 1 Trends of exports in Fiji (a-d) ( Source Reserve Bank of Fiji, 2020; World Bank, 2020)

tourism earnings doubled from $\$ 300 \mathrm{~m}$ in 1990 to over $\$ 600 \mathrm{~m}$ by 2015 (in 2010 prices). It has shown a very progressive trend, especially following the periods of political disturbances in 1987, 2000, and 2006. Since 2007, data on tourism earnings show a very strong upward trend and this is largely due to a stable political environment, increased tourism marketing, and improved tourism packages. Other important stimulus includes encouraging coordination among stakeholders and expanding international markets beyond Australia and New Zealand. In 2020, however, total visitor arrivals declined a mammoth $85 \%$ to just over 30,000 in the 3rd quarter of 2020, relative to the same period in 2019 (Pacific Community 2020). Singh et al (2021) argue that it could take as much as 19 months (up to October 2021) for the full recovery of the industry in Fiji. Nevertheless, in the normal years, visitor arrivals averaged over 900,000 per annum earning just over \$1611.6 m gross revenue for Fiji (Reserve Bank of Fiji 2020).

Gold is another important export commodity for Fiji since the 1930s. After a period of low productivity and industrial strives, the mine changed a few ownerships and recently operates successfully as Vatukoula Gold Mines, which has invested a massive US\$6 m in 2019 in updating their gold processing equipment (Investment Fiji 2020b). Historically, the contribution of gold had been just over 
8\% to Fiji's GDP (Reserve Bank of Fiji 2020). Data show that from 1996 real earnings from gold increased by $50 \%$ from US\$40 m (Fig. 1d), with declined temporarily for a brief period since 2004 due to a fall in the demand for gold from the EU market. In 2010, the earning increased to US\$77 $\mathrm{m}$ but gold production declined thereafter due to the decline in the world market price, low productivity, bad quality ore extraction, and high fuel cost. Industrial tensions around this time were also a significant deterrent to the productivity of the mine. The recent updates show that gold export receipts recorded an increase of $14.6 \%$ due to higher prices in the international market, and gold production is expected to increase (Reserve Bank of Fiji 2020).

\section{Modelling Framework}

Empirical modelling of trade comprises global trade analysis (GTAP), export demand functions, and gravity models. ${ }^{4}$ Pratt (2014) has used Computable General Equilibrium (CGE) to explain the economic impact of devaluation on tourism in Fiji under a small open market economy set-up. CGE models are more appropriate for simulations and for studying the interaction of various prices levels such as factor price, production price, and exchange rate. Ram and Prasad (2007) is an example of the gravity model applied to Fiji in the context of the global trade potential of Fiji. Since CGE models require perfect market and institutional or behavioural assumptions, we stick to modelling an export demand function to investigate the determinants of export components. The modelling framework adopted is similar to Senhadji and Claudio (1998), Rao and Singh (2007), and Kumar (2014). ${ }^{5}$ Our present paper differs in the application of the model to the specific components of exports (rather than aggregate exports) so that policymakers may get a better view of sector-specific export promotion strategies. This is useful because SVEs like Fiji cannot compete in all the commodity markets. In addition, they neither can support all domestic industries. Therefore, those less productive industries can be re-engineered to reflect the needs and aspirations of the economy and international markets. This would create a better allocation of resources and more strategic sectorial development along with the premise of creative destruction, Schumpeter (1942). This is supported by the Heckscher-Ohlin Theory. Heckscher (1919) and Ohlin (1933) argue that countries may specialise in commodities that they produce efficiently due to the

\footnotetext{
4 A GTAP is a comprehensive state-of-the-art variant of the Computable General Equilibrium (CGE) model used in trade policy debates (e.g. WTO rulings and foreign policy). However, GTAP and CGE models are data demanding, with a Fiji GTAP yet to be developed. Though Ram and Prasad (2007) have developed some extend of gravity model to Fiji, an up-to-date Fiji CGE model is Oum and Singh (2019) and Pratt (2014) that will be a very useful resource for developing an appropriate GTAP model for Fiji. The Gravity Model draws upon Newton's idea of how a mass at origin $i$ is attracted to location $\mathrm{j}$ impacted by the distance and other potential deterrents in-between $i$ and $j$. Tinbergen (1962) pioneered the application of gravity concept in explaining trade flow. This been extended to include other features like trade costs, demand-supply constraints, choices, etc.

5 Kumar (2014) used this framework to explain why the Reserve Bank of Fiji's approach to managing imports through interest rate is flawed.
} 
intensity of resource endowment. We think that with the limitations of resources in the SVEs, countries can better allocate the use of existing resources to benefit from similar efficiency advantages.

We take exports as a function of foreign income (proxied by weighted average income) of the trading partner countries and relative prices adjusted for the effective exchange rate. In the model below, $R X$ represents real exports, $Y^{*}$ trading partner income, and $P$ and $P^{*}$ are domestic and trading partner prices of the exportable respectively. Where data are limited, we use GDP deflator or unit value of exports on a common 2010 base. $\mathrm{E}$ is the nominal effective exchange rate defined as the price of foreign currency in domestic currency. Thus, the basic model is specified as follows:

$$
\ln R X_{t}=\text { const }+\beta_{1} \ln Y_{t}^{*}+\beta_{2} \ln \left(E \times \frac{P_{t}^{*}}{P_{t}}\right)+\beta_{1} \ln Z_{t}+e_{t}
$$

Here, $Z$ is a composite set of other potential determinants of exports as dictated by the literature and $e$ is the error term. A closer examination of the econometric requirements in (1) suggest the importance of pre-testing for time series properties of variables-it is known that most macro variables are non-stationary. Second, it also requires a suitable method of estimation whereby the dynamic structure is consistent with the data generation process. In empirical works, there is no guarantee that these can be satisfactorily established especially with time-series data. After satisfactorily establishing the order (unit-roots) of variables, we use Phillip-Hansen (1990) method to estimate the integrating vector which is suitable when there are reverse causation and potential heteroscedasticity in errors, see Senhadji (2000) for an explanation.

We also obtain the dynamic estimates based on LSE-Hendry's General to Specific framework, due to Hendry et al. (1984), which is capable of handling estimation consistent with the data generation process. ${ }^{6}$ Hendry et al. (1984) state that if the theory is correct, we can relate theoretically consistent variables without empirically testing for unit root or identification. In addition, if a combination of variables changes over time, Hendry et al. (1984) argue that there would be only two reasons for this to happen. First, it could be due to changes in the determinants and second, due to adjustment to long-run equilibrium when the market stabilises. The philosophy of Hendry's method can be summarised as follows:

Suppose output (y) depends on two inputs ( $\mathrm{x}$ and $\mathrm{z}$ ) such as: $y_{t}=\alpha x_{t}+\beta z_{t}+\varepsilon_{t}$, where $\mathrm{x}$ and $\mathrm{z}$ are the two inputs and $\varepsilon$ the error term, then change in $\mathrm{y}$ could be due to the following:

1. Change in its determinants, that is, $\Delta y_{t}=\alpha \Delta x_{t}+\beta \Delta z_{t}$, which essentially includes the current and past changes of the independent variables and past changes of the dependent variable.

\footnotetext{
${ }^{6}$ The LSE-Hendry's GETS framework can estimate the first- and second-stage equations in one-step, which is much more efficient.
} 
2. The adjustment to long-run equilibrium, that is: $\Delta y_{t}=-\lambda\left(y_{t-1}-\left(\alpha x_{t-1}+\beta z_{t-1}\right)\right)$, where $\lambda$ indicates the speed of adjustment.

The statistical significance of $\lambda$ is used as proof of the existence of a stable relationship between the variables $(y, x$, and $z){ }^{7}$ This and the unit root test are secondary in LSE-Hendry's method, which argues that any change in the dynamics of $y$ would be a combination of (1) and (2) if the theory is correct. ${ }^{8}$ Note that of the two components stated above, the first indicates the short-run effects while the other shows the long-run effects. The LSE-Hendry's specification for a more general dynamic specification of (1) is given in (2) as follows: In its general unrestricted form, the aggregate export function would be as follows:

$$
\begin{aligned}
& \Delta \ln X_{t}=-\lambda\left[\ln X_{t-1}-\left[\alpha_{0}+a_{1} \ln Y_{t-1}^{*}+a_{2} \ln \left(E_{t-1} \times\left(\frac{P_{t-1}^{*}}{P_{t-1}}\right)\right)\right]\right]+\beta_{1 i} \sum_{i=1}^{n} \Delta \ln X_{t-i} \\
& +\beta_{2 i} \sum_{i=0}^{n} \Delta \ln Y_{t-i}^{*}+\beta_{3 i} \sum_{i=0}^{n} \Delta \ln E \times\left(\frac{P^{*}}{P}\right)_{i t-i}+\varepsilon_{t} .
\end{aligned}
$$

Other dynamic influences on Fiji's export like the political events in 1987, 2000, and 2006 are captured by including dummy or lagged changes in these other variables (as part of the vector of other variables) introduced in (2). Standard variable deletion test is used to arrive at the most parsimonious version. Due care is taken to minimise the path dependency bias, autocorrelation, heteroscedasticity, and other diagnostic problems. In a model where a few variables are related, there is no guarantee that inter-dependencies do not exist. Due to the potential endogeneity, we used instrumental variables to control for reverse causation. Multi-collinearity is easily understood as the inter-relationships between the included set of independent variables in the regression equation, and if this happens, the exact influences of each included variable are unknown and distorted, but not so much the model's forecasting ability. However, establishing such clarity is a worthwhile task. ${ }^{9}$

Before turning to empirical results, we may mention that there exists an alternative technique, called the vector error correction model (VECM) for estimating export demand functions. The drawback of this model is that it does not allow us to detect the direction of causality between the variables. On the other hand, Hendry's general-to-specific approach is found to report better results than VECM in some studies (Rao and Singh 2005a, 2005b, 2005c; Rao and Rao 2005a, 2005b). Moreover, the general to specific approach is simple to use and its results do not conflict with VECM. Hence, the decision to use the general-to-specific approach in this paper.

\footnotetext{
7 Ericsson and MacKinnon (2002) provide critical values for this test.

8 The Unit root test has been conducted despite Hendry's argument to satisfy time-series proponents.

9 Tests of robustness originate from the works of Leamer (1983), where alternative variable selection is tested at $95 \%$ level.
} 


\section{Data, Estimation, and Results}

\section{Data and Variables}

The dataset used in the estimation of models is derived from various sources. The details are provided in Table 4 in Appendix . All observations are measured on annual frequencies from 1970 to 2018 . Exports are deflated by the 2010 export unit value index. For commodity-specific exports, the real values are derived by deflating with the respective unit value indices, base 2010. $Y^{*}$ is the trade-weighted average trading partner's real income while $E$ is the nominal exchange rate. The trade weights are used to estimate a weighted exchange rate, which closely resembles Fiji's nominal effective exchange rate, whereby a rise in $E$ represents a depreciation of the Fiji dollar. $P^{*}$ is the trade-weighted average GDP deflator or commodityspecific unit value indices (2010 base) of the trading partner countries $(i)$. A depreciation of the Fiji dollar or a raise in $P^{*}$ is expected to promote Fijian goods and services in foreign markets. A rise in domestic prices is likely to lower Fiji's exports. However, these issues are empirical in nature.

Other sector-specific variables and the dummies that are used to capture bad weather and political disturbances are specified as follows. For the sugar sector, $\mathrm{RX}_{\mathrm{SUG}}$ is the real value of exports of sugar. SS is a proxy for supply shock- the ratio of tons of cane to tons of sugar, implying a rise in this ratio signals a decline in yield per hectare or a decline in sugar productivity. CLIMAT is a dummy variable used to capture adverse weather conditions. ${ }^{10}$ These data are obtained from the Fiji Islands Bureau of Statistics. For the tourism sector, $\mathrm{RX}_{\mathrm{TSM}}$ is the real value of exports of tourism, and a COUP dummy resembles the political disturbances in 1987, 2000, and 2006. ${ }^{11}$ Quality of services (QS) (proxied by the average length of stay of visitors) is likely to promote Fiji's tourism. Data are obtained from the Fiji Islands Bureau of Statistics and the Reserve Bank of Fiji. Gold export demand function relates real values of gold exports $\left(\mathrm{RX}_{\mathrm{GLD}}\right)$ to the square of actual gold production as a measure of the scale of activity (SC) and wage rates in the mining sector deflated by the GDP deflator is used to proxy industrial strives. These data were obtained from the Fiji Islands Bureau of Statistics, the Reserve Bank of Fiji (2019), and the International Finance Statistics (2019). A basic summary of data-mean, standard deviation, and minimum and maximum values of variables presented in Table 5 in Appendix show considerable variations. In addition, there was no evidence of multicollinearity among variables used in this study.

\section{Estimates of Long-Run Commodity-Specific Elasticities}

Having established the unit root order of variables using data from 1970 to 2018 (see Table 1), the long-run cointegrating vectors are estimated based on Phillips-Hansen

\footnotetext{
10 This is derived as 1 for years when there was either one or all of flooding, cyclone, or drought; or is zero otherwise, see SPC Geoscience program: http://gsd.spc.int.

11 This is indicated by value 1 in the year of coups and the rest of the years $=0$.
}

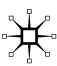


(1990) method. The results are presented in Table $2 .{ }^{12}$ The table shows the long-run elasticities for aggregate exports, as well as for the three sectors-sugar, tourism, and gold. These results reveal that relative price and trading partner income are the important determinants of Fiji's aggregate exports. The elasticity of exports with respect to relative price is 0.22 . This is low but not implausible. It implies that about $5 \%$ nominal devaluation of the Fiji dollar is required to increase real exports by $1 \%$ if relative prices remain unchanged. This is consistent with the results reported in Kumar (2014). In the Fijian context, the estimated nominal exchange rate passthrough is about 60\% (Reserve Bank of Fiji 2019), which indicates that the real impact of devaluation will be much lower, requiring large devaluation. Trading partner real income has a significant positive impact on aggregate exports of about $0.9 \%$ for each $1 \%$ increase in exports and this is plausible for Fiji. This result is similar to those presented in Rao and Singh (2007), Kumar (2009, 2014), and Prakash and Maiti (2016).

While these results are useful, our primary interest lies in sectoral export elasticities. Both the foreign income and relative prices are highly significant determinants of sugar exports (see Col. 2 of Table 2). Income elasticity for sugar exports is greater than unity confirming that even though sugar is not a luxury good for the trading partners, the EU (where most of Fiji's sugar is exported) pays three times the world market price. Second, a devaluation of the Fiji dollar or adjustment to relative prices have a stronger impact on sugar exports than on aggregate or any of the other two exports. However, inefficiency reflected in the higher TCTS ratio ${ }^{13}$ reduces real exports and incomes in the sugar sector. Over time, sugar exports have shown a strong negative growth trend, indicating a decline in income. This calls on a renewed approach to improve the production and export of sugar.

Column 3 of Table 2 presents the income elasticity for tourism. This elasticity is 0.7 and statistically significant which suggests that a $1 \%$ increase in the trading partner income will increase tourism but by less than $1 \%$. As such, it implies that Fiji tourism is not a luxury for the trading partners who have relatively better tourism products-it is hard to argue that Fiji tourism products are better than what is available in Australia, the USA, NZ, and the EU (Fiji's traditional markets) although Fiji offers holiday destination to the visitors. Relative price seems to have a significant impact on tourism but with a small elasticity, hence it is doubtful if nominal devaluation will significantly promote Fiji tourism in the long run. Estimates also show that better quality of services and fewer political disturbances would promote tourism in Fiji.

Finally, the long-run results for gold exports show a small yet statistically significant income elasticity (Col. 4 of Table 2). This could imply that Fijian gold is of incomparable (or say of lower) quality and therefore demand fails to respond as expected. The effect of relative price on gold exports is low, however, statistically

\footnotetext{
12 In this method, the Cointegrating Vectors (CV) are obtained with standard errors of the estimated coefficients. No other residual or diagnostic tests are produced for the CVs. The data sample is 19702018.

13 TCTS (Tons Cane to Tons Sugar) is an empirical measure of sugar productivity.
} 
Table 1 Unit root tests

\begin{tabular}{|c|c|c|c|c|}
\hline Variable & Order & ADF-statistics & $\mathrm{CV}$ & Conclusion \\
\hline LYL & 0 & 2.23 & 3.50 & $\mathrm{I}(1)$ \\
\hline DLYL & 0 & 7.76 & 2.92 & $\mathrm{I}(0)$ \\
\hline LKL & 2 & 2.18 & 3.50 & $\mathrm{I}(1)$ \\
\hline DLKL & 0 & 3.17 & 2.92 & $\mathrm{I}(0)$ \\
\hline LRX & 0 & 3.27 & 3.50 & $\mathrm{I}(1)$ \\
\hline DLRX & 1 & 6.76 & 2.92 & $\mathrm{I}(0)$ \\
\hline LRP & 0 & 4.02 & 3.52 & $\mathrm{I}(1)$ \\
\hline DLRP & 0 & 7.22 & 2.94 & $\mathrm{I}(0)$ \\
\hline LH & 0 & 1.41 & 3.50 & $\mathrm{I}(1)$ \\
\hline DLH & 0 & 7.18 & 2.92 & $\mathrm{I}(0)$ \\
\hline $\mathrm{LY}^{*}$ & 1 & 2.99 & 3.52 & $\mathrm{I}(1)$ \\
\hline DLY* & 0 & 4.91 & 2.94 & $\mathrm{I}(0)$ \\
\hline $\mathrm{LRX}_{\mathrm{SUG}}$ & 4 & 1.59 & 3.54 & $\mathrm{I}(1)$ \\
\hline $\operatorname{DLRX}_{\mathrm{SUG}}$ & 4 & 3.28 & 2.95 & $\mathrm{I}(0)$ \\
\hline $\mathrm{LRP}_{\mathrm{SUG}}$ & 0 & 3.58 & 3.54 & $\mathrm{I}(1)$ \\
\hline $\mathrm{DLRP}_{\text {SUG }}$ & 4 & 4.52 & 2.95 & $\mathrm{I}(0)$ \\
\hline LSS & 2 & 3.42 & 3.54 & $\mathrm{I}(1)$ \\
\hline DLSS & 0 & 5.86 & 2.95 & $\mathrm{I}(0)$ \\
\hline LQS & 0 & 2.26 & 3.54 & $\mathrm{I}(1)$ \\
\hline DLQS & 0 & 6.14 & 2.95 & $\mathrm{I}(0)$ \\
\hline $\mathrm{LRP}_{\mathrm{TSM}}$ & 0 & 2.28 & 3.54 & $\mathrm{I}(1)$ \\
\hline $\mathrm{DLRP}_{\mathrm{TSM}}$ & 0 & 5.86 & 2.95 & $\mathrm{I}(0)$ \\
\hline $\mathrm{LRX}_{\mathrm{TSM}}$ & 0 & 3.31 & 3.54 & $\mathrm{I}(1)$ \\
\hline $\operatorname{DLRX}_{\mathrm{TSM}}$ & 0 & 7.41 & 2.95 & $\mathrm{I}(0)$ \\
\hline $\mathrm{LRP}_{\mathrm{GLD}}$ & 1 & 1.88 & 3.54 & $\mathrm{I}(1)$ \\
\hline $\operatorname{DLRP}_{\mathrm{GLD}}$ & 0 & 6.58 & 2.95 & $\mathrm{I}(0)$ \\
\hline $\mathrm{RX}_{\mathrm{GLD}}$ & 0 & 3.27 & 3.54 & $\mathrm{I}(1)$ \\
\hline $\mathrm{DRX}_{\mathrm{GLD}}$ & 0 & 7.75 & 2.95 & $\mathrm{I}(0)$ \\
\hline LCPI & 0 & 2.89 & 3.54 & $\mathrm{I}(1)$ \\
\hline DLCPI & 0 & 8.77 & 2.95 & $\mathrm{I}(0)$ \\
\hline LSC & 0 & 2.23 & 3.54 & $\mathrm{I}(1)$ \\
\hline DLSC & 0 & 6.58 & 2.95 & $\mathrm{I}(0)$ \\
\hline LRW & 0 & 1.07 & 3.54 & $\mathrm{I}(1)$ \\
\hline DLRW & 0 & 4.88 & 2.95 & $\mathrm{I}(0)$ \\
\hline
\end{tabular}

Up to 4 lags were tested. Results implied unit root in levels and stationery in first differences. Variables in levels included intercept and trend, but no trend term included in first difference equations. All tests conducted in M-FIT 4.1

significant. It implies that a strong devaluation is needed to boost the international demand for gold. Higher real wage cost reduces gold mine's ability to be competitive, and thus wages negatively affect gold production. The impact of scale variables is positive and signals that large economic gains are possible if Fiji considers 
Table 2 Estimated long run cointegrating vectors (Eq. 1)

\begin{tabular}{lllll}
\hline & Aggregate & Sugar & Tourism & Gold \\
\hline Constant & $2.950(0.00)$ & $12.142(0.00)$ & $2.242(0.00)$ & $-0.007(0.96)$ \\
$\ln Y_{t} *$ & $0.912(0.00)$ & $1.212(0.06)$ & $0.711(0.00)$ & $0.267(0.00)$ \\
$\ln \left(E \times \frac{P_{i t}^{*}}{P_{i t}}\right)$ & $0.224(0.05)$ & $0.811(0.03)$ & $0.260(0.02)$ & $0.167(0.02)$ \\
Time & - & $-0.071(0.03)$ & - & - \\
$\ln S S_{t}$ & - & $-1.848(0.00)$ & - & - \\
$\operatorname{COUP}$ & - & - & $-0.108(0.00)$ & - \\
$\ln Q S_{t}$ & - & - & $0.373(0.07)$ & - \\
$\ln S C_{t}$ & - & - & - & $0.429(0.00)$ \\
$\ln R W_{t}$ & - & - & - & $-0.248(0.03)$ \\
\hline
\end{tabular}

Sample (1970-2018). The standard errors are in parentheses. The Phillips-Hansen (1990) method is used with truncation lags where the coefficients stabilised, normally at $1 / 3$ of the sample size

improving the scale of operations in gold mines. The existing capacity in gold production is likely to boost exports in the long run.

\section{Dynamic Estimates and Implications for Trade Policy}

The dynamics estimates of export demand (Table 3) are generated with LSE-Hendry's General to Specific method. The idea is to benefit from single-step estimation (to gain parameter efficiency) and conduct a sensitivity test on the co-integration vectors (CVs), as in LSE-Hendry's method, a larger set of dynamic variables are added to the VAR. All estimates show a good fit to the data, and the diagnostic tests for the null hypotheses of no serial correlation, functional form misspecification, non-normality, and heteroscedasticity are insignificant at 5\% level. Lambda $(\lambda)$ is the coefficient of error correction term, and it is strongly negative and close to unity for tourism and gold, implying the existence of persistent feedback systems. The convergence to equilibrium is slower for the sugar sector and aggregate exports. Nevertheless, a significant and negative value implies a well-converging model with a valid long-run relationship(s). Higher speed to adjustment and validity in estimates are useful for intervention policies.

The estimates presented in Table 3 (Col. 1) show that total exports respond positively with the rise in relative price (RP) and trading partner income ( $\left.Y^{*}\right)$. The natural disasters (CLIMAT) and political disturbances (POLDEV) seem to worsen the aggregate export performance in Fiji. A natural disaster such as cyclone or flooding which is common in Fiji adversely affects agricultural production leading to lower exports. Political disturbances create an atmosphere of uncertainty affecting adversely total investment, production, and exports.

In the sugar sector, productivity shocks (SS), natural disasters, and political disturbance are found to adversely affect production and exports. Supply-side and trade facilitation factors such as poor road condition, shortage of regular and relatively cheap supply of labour, burning of cane, and adverse weather condition have badly 
Table 3 Estimated dynamic of exports (Eq. 2)

\begin{tabular}{|c|c|c|c|c|}
\hline & Aggregate & Sugar & Tourism & Gold \\
\hline Constant & $0.063[0.04]^{*}$ & $0.185[0.00]^{* *}$ & $0.787[0.00]^{* *}$ & $0.019[0.60]$ \\
\hline$\lambda$ & $-0.43[0.00]^{* *}$ & $-0.409[0.00]^{* *}$ & $-0.931[0.00]^{* *}$ & $-1.276[0.00]^{* *}$ \\
\hline$\Delta \ln R P_{t}$ & $0.613[0.00]^{* *}$ & - & - & $0.365[0.01]^{* *}$ \\
\hline$\Delta \ln R P_{t-1}$ & $0.346[0.02]^{* *}$ & $-0.638[0.00]^{* *}$ & - & - \\
\hline$\Delta \ln R P_{t-3}$ & - & $-0.217[0.07]$ & - & $0.293[0.03]^{*}$ \\
\hline$\Delta \ln Y_{t}^{*}$ & $1.414[0.00]^{* *}$ & - & - & $1.489[0.01]^{* *}$ \\
\hline$\Delta \ln Y_{t-2}^{*}$ & - & - & $-0.654[0.00]^{* *}$ & - \\
\hline$\Delta \ln R X_{t-2}$ & - & $-0.431[0.00]^{* *}$ & $-0.146[0.02]^{* *}$ & - \\
\hline$\Delta \ln P_{t-1}$ & - & $0.988[0.00]^{* *}$ & - & - \\
\hline$\Delta \ln S S_{t-2}$ & $-0.207[0.03]^{*}$ & $-0.658[0.02]^{* *}$ & - & - \\
\hline$\Delta \ln Q S_{t-1}$ & - & - & $-1.167[0.01]^{* *}$ & - \\
\hline$\Delta \ln S C_{t}$ & - & - & - & $0.256[0.00]^{* *}$ \\
\hline$\Delta \ln S C_{t-1}$ & - & - & - & $-0.149[0.01]^{* *}$ \\
\hline$\Delta \ln R W_{t-1}$ & - & - & - & $-1.046[0.00]^{* *}$ \\
\hline CLIMAT & $-0.073[0.06]$ & $-0.009[0.00]^{* *}$ & - & - \\
\hline POLDEV & $-0.247[0.00]^{* *}$ & $-0.098[0.02]^{* *}$ & $-0.119[0.01]^{* *}$ & $-1.153[0.00]^{* *}$ \\
\hline $\bar{R}^{2}$ & 0.616 & 0.768 & 0.923 & 0.925 \\
\hline SER & 0.112 & 0.100 & 0.069 & 0.17 \\
\hline$\chi_{(s c)}^{2}$ & $0.12[0.73]$ & $1.95[0.16]$ & $3.56[0.06]$ & $1.487[0.23]$ \\
\hline$\chi_{(f f)}^{2}$ & $1.85[0.17]$ & $0.23[0.62]$ & $5.593[0.21]$ & $2.936[0.08]$ \\
\hline$\chi_{(n)}^{2}$ & $2.82[0.24]$ & $1.86[0.39]$ & $0.218[0.89]$ & $3.537[0.17]$ \\
\hline$\chi_{(h s)}^{2}$ & $0.23[0.63]$ & $1.84[0.18]$ & $0.814[0.97]$ & $0.737[0.97]$ \\
\hline
\end{tabular}

Standard errors of the coefficients are in brackets. Variables significant at $5 \%$ are denoted with $*$ and those at $1 \%$ with **. Chi-square tests (LM version) are for serial correction $(S C)$, functional form misspecification $(f f)$, normality in residuals $(n)$, and heteroscedasticity $(h s)$. Sample is 1970-2018

affected the sugar industry. The previous period's growth in exports (RX) and relative prices seem to reduce export earnings, probably reflecting the uncertainties surrounding the sugar industry. Inflation expectations $\left(\Delta \ln P_{t-1}\right)$ seem to stimulate farmers to increase production and trade, to hedge against uncertainty.

The political disturbances adversely affect tourism. Other variables such as quality of services (QS) adversely affect tourism earning in the short run probably because of the availability of bag-packers and cheaper accommodation options. However, unlike the sugar sector, tourism is more resilient, with twice as fast a speed of adjustment. It takes about two and a half years for sugar to revert to equilibrium once disturbed but tourism takes just about a year.

The increases in trading partner income and relative prices boost gold exports. A reduction in real wages (RW, a proxy for the cost of production) increases exports earnings, the political disturbances impact gold inversely. Estimates also show that while immediate effects of improvements in a scale of operations (SC) improve exports, its lagged effects are negative. Devaluation of the Fiji dollar and political 
disturbances have affected exports in all sectors in the short run. This signals the need to develop domestic capacity and strong institutions.

Having discussed the dynamic estimates of export demand, we now turn to the question of stability of exports earnings in the light of Fiji's vulnerability to natural disasters. Like other vulnerable small economics, Fiji also has little resilience capability to fight against natural disasters (Paul 2020). It is well known that natural calamities adversely affect the production and exports of sugar. Moreover, Fiji has a lower export base and depends largely on the exports of sugar, tourism, and gold for foreign earnings. The studies undertaken in developing countries reveal that export diversification provides greater stability to export earnings and leads to higher economic growth, see Marian and Milne (1987), Hesse (2008), and Sarin et al (2020). Export diversification is described as an increase in the number of distinct products in the export base to reduce dependence on any one product as a source of foreign exchange earnings. This suggests that, in addition to the exports of sugar, tourism, and gold, Fiji may like to concentrate on the food processing of fruits, vegetables, root crops, and seafood which may have huge export potentials. This policy option is worth exploring.

\section{Conclusions}

The previous studies of exports performance in Fiji were carried out at the aggregate level. We have conducted a disaggregated analysis of exports of three major products, namely, sugar, tourism, and gold. This analysis is useful for developing sector-based export promotion policies. The long run as well as dynamic export demand functions are estimated at the aggregate and disaggregate levels. The results identify a number of factors such as trading partner income, relative prices, productivity shocks, natural disasters, political disturbances, and the exchange rate that affect the export demand for sugar, tourism, and gold, though not in the same way. For instance, tourism and sugar enjoy the highest income elasticity. Sugar export is adversely affected by natural calamities and political upheavals. The political upheavals also adversely affect tourism in Fiji. The exchange rate affects the export of sugar more than others. The idea that devaluation will promote exports in Fiji needs careful investigation because results show that this will happen with a high cost, i.e. $5 \%$ nominal devaluation will be required to increase real exports by $1 \%$.

Finally, we note that the spread of the covid-19-which is a global shock-has led to border restrictions implying reduced ability to trade internationally (Tröster and Küblböck 2020). This global shock has adversely affected the tourism industry 
in Fiji and other small island economies where tourism has been a major source of earnings. But what is more important is to know the long-run implications of this kind of global shock for the tourism economy. While it is too early to highlight the long-term implications of the crisis with a certain degree of confidence, some long-run possibilities may well be delineated. One possibility is that virtual tourism could substitute for actual travel. Virtual tourism allows customised and accessible information. It enables online visitors to visit museums and a range of attractions, to learn about specific objects of interest, and to read blog postings about exhibitions. This change in consumer behaviour might have a lasting impact on global $\mathrm{CO}_{2}$ emissions. Second, the emergence of new technologies such as video conferencing is likely to affect travel especially to far off destinations and reduce costs and time. Third, travel options might also be reduced in future. With many world countries continuing their quarantine, airlines are warning of bankruptcy, hotels are closed, and tourist buses remain empty. The airline companies that survive may cut their routes to small regional destinations which may result in fewer tourists requiring accommodation in these destinations, and many hotels closing. Fourth, some developing countries dependent on tourism might consider diversifying resources away from tourism. For example, in the case of Fiji, both primary production and food processing of fruits, vegetables, root crops, livestock, and seafood have huge export potentials. This kind of export diversification could reduce dependency on tourism in the long run.

\section{Appendix}

See Tables 4 and 5. 


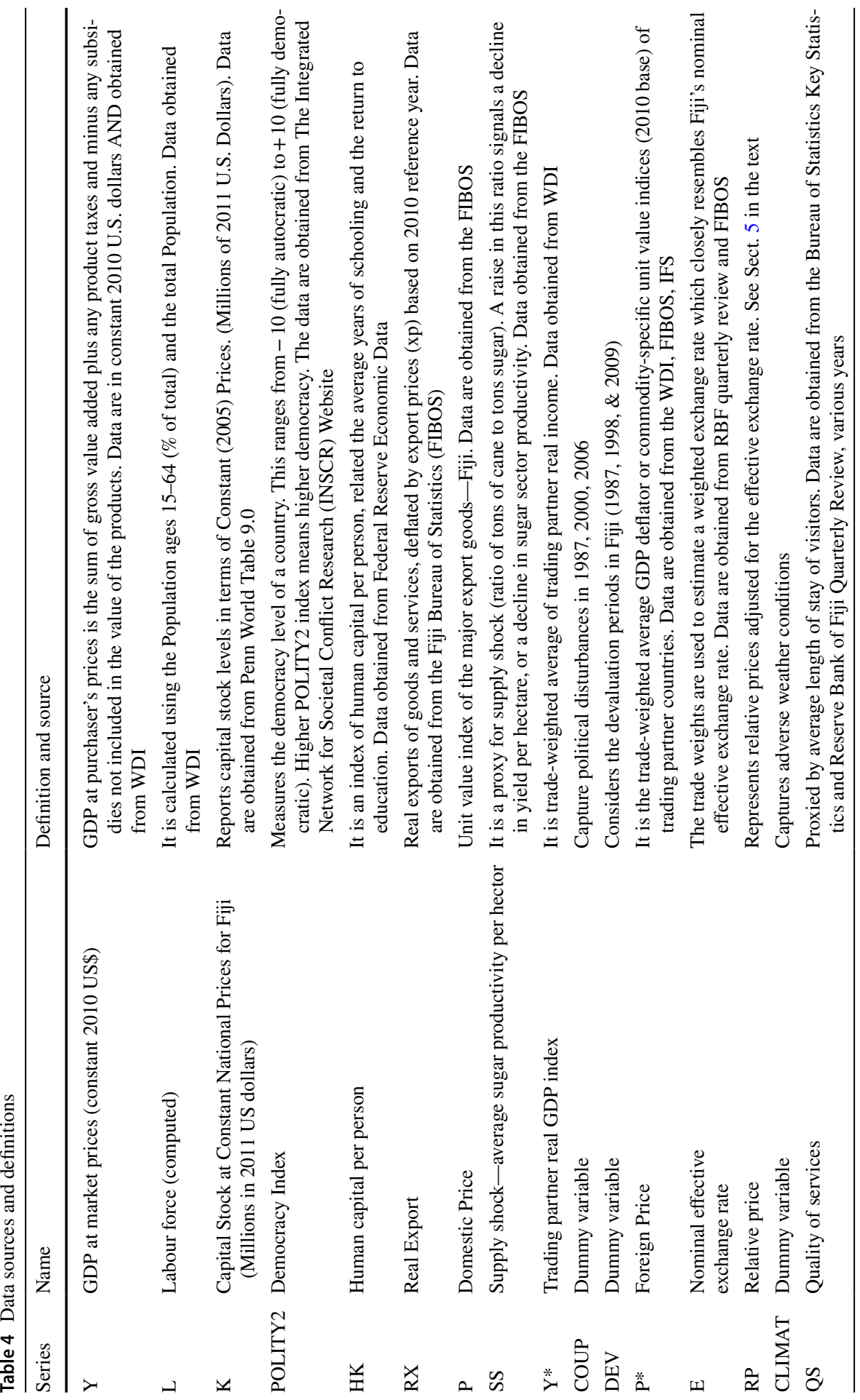




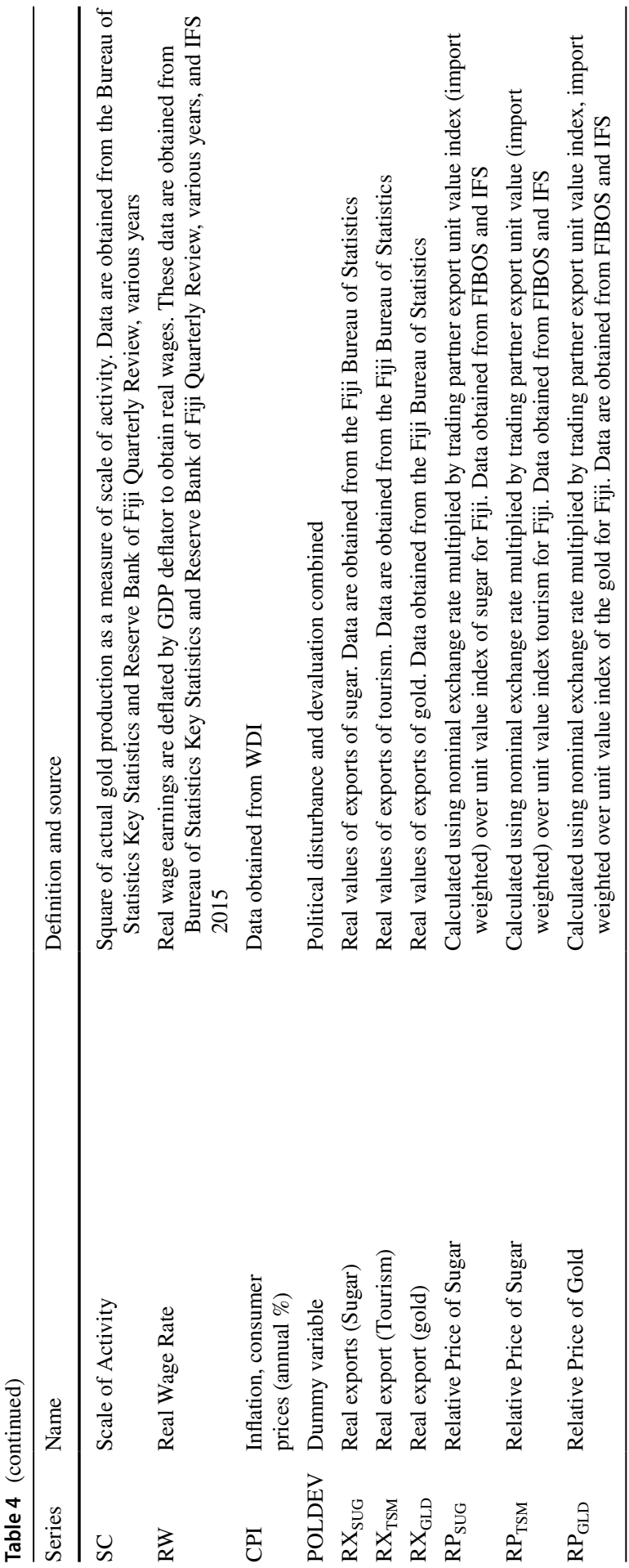

舟远 
Table 5 Summary statistics of variables

\begin{tabular}{lllrll}
\hline Variable & Obs & Mean & \multicolumn{1}{l}{ Std. Dev } & Min & Max \\
\hline $\mathrm{Y}$ & 46 & $2,075,371,892$ & $114,477,789.6$ & $697,947,691.7$ & $3,880,405,926$ \\
$\mathrm{~L}$ & 46 & 410,453 & $15,706.2$ & 194,865 & 583,680 \\
$\mathrm{~K}$ & 46 & $9,485,771,556$ & $475,659,805.3$ & $3,718,519,287$ & $16,558,568,702$ \\
$\mathrm{HK}$ & 46 & $1,671,552.97$ & $66,853.59$ & $891,250.21$ & $2,373,105.7$ \\
$\mathrm{RX}$ & 46 & 1565.65 & 857.23 & 499.60 & 3229.47 \\
$\mathrm{P}$ & 46 & 95.87 & 7.70 & 14.4 & 199.08 \\
$\mathrm{SS}$ & 46 & 51.63 & 1.35 & 31.87 & 69.1 \\
$\mathrm{Y} *$ & 46 & 114.80 & 8.85 & 43.57 & 221.62 \\
$\mathrm{P} *$ & 46 & 99.40 & 8.54 & 23.52 & 242.52 \\
$\mathrm{E}$ & 46 & 1.23 & 0.03 & 0.882 & 1.64 \\
$\mathrm{RP}$ & 46 & 1.31 & 0.04 & 0.80 & 2.06 \\
$\mathrm{QS}$ & 46 & 8.86 & 0.08 & 7.9 & 9.8 \\
$\mathrm{RW}$ & 46 & 16.02 & 1.66 & 5.16 & 30.48 \\
$\mathrm{CPI}$ & 46 & 57.62 & 4.39 & 17.63 & 113.12 \\
$\mathrm{RX}$ & 46 & 318,138 & $15,989.2$ & 110,823 & 500,383 \\
$\mathrm{RX}_{\text {TSM }}$ & 46 & 514.08 & 67.04 & 61.4 & 1560 \\
$\mathrm{RX}_{\text {GLD }}$ & 46 & 44.59 & 3.49 & 1.45 & 95.52 \\
\hline
\end{tabular}

\section{References}

ADB. 2015. Integrating SMEs into Global Value Chains. Challenges and Policy Actions in Asia. Mandaluyong City: Asian Development Bank Institute.

ADB. 2018. Aid for Trade in Asia and the Pacific: Promoting Connectivity for Inclusive Development, Manila.

ADB. 2020. Revitalizing the Fiji Economy. Metro Manila, Philippines.

Alam, I. 2003. Manufactured Exports, Capital Good Imports, and Economic Growth: Experience of Mexico and Brazil. International Economic Journal 17 (4): 85-105.

Armstrong, H., and R. Read. 2006. Geographical Handicaps and Small States: Some Implications for the Pacific from a Global Perspective. Asia Pacific Viewpoint 47 (1): 79-92.

Asafu-Adjaye, J. 1999. Exchange rate variability and export growth in Fiji. Asia Pacific School of Economics and Management Working Papers \#99/4, Australian National University.

Balassa, B. 1978. Exports and Economic Growth: Further Evidence. Journal of Development Economics 5 (2): 181-189.

Chand, R., D. Jain, R. Singh, and A. Patel. 2020. Export Performance, Governance, and Economic Growth: Evidence from a Small and Vulnerable Economy- Fiji Islands. Cogent Economics \& Finance 8 (1): 1-16.

Chow, Y. 1987. Causality between Export Growth and Industrial Development: Empirical Evidence from Newly Industrialised Countries. Journal of Development Economics 28 (1): 265-276.

Deo, D. 2019. Linkage and Retention of Tourism Earnings in Fiji, Master thesis, the University of the South Pacific (Suva) Fiji. (Unpublished).

Ericsson, N., and J. MacKinnon. 2002. Distributions of Error Correction Tests for Cointegration. Econometrics Journal 5 (2): 285-318.

FIBOS. 2020. Key Statistics. Fiji Islands Bureau of Statistics, Suva.

Food and Agriculture Organization. 2017. Smallholder Agriculture and Market Participation. http://www. fao.org/3/a-i7841e.pdf

Fugazza, M. 2004. Export Performance and Its Determinants: Supply and Demand Constraints. United Nations Publications. 
Giles, J., and C. Williams. 2000. Export-led Growth: A Survey of the Empirical Literature and Some Non-causality Results: Part 1. Journal of International Trade and Economic Development 9 (3): 261-337.

Gounder, R. 2004. Fiji's Economic Growth Impediments: Institutions, Policies, and Coups. Journal of the Asia Pacific Economy. 9 (3): 301-324.

Heckscher, E. 1919. The Effect of Foreign Trade on the Distribution of Income. Theory of International Trade 4 (21): 497-512.

Hendry, D., A. Pagan, and J.D. Sargan. 1984. Dynamic Specification. In Handbook of Econometrics, vol.2, eds. Grilliches, Z. and M. Intriligator. Amsterdam (North-Holland).

Hesse, H. 2008. Export Diversification and Economic Growth. Commission on Growth and Development Working Paper No. 21. World Bank, Washington, DC. (C) World Bank. https://openknowledge.world bank.org/handle/10986/28040 License: CC BY 3.0 IGO.

International Finance Statistics. 2019. IMF DATA, https://data.imf.org/?sk=4c514d48-b6ba-49ed-8ab952b0c1a0179b.

International Trade Centre. 2020. WTO Trade Policy Review: Fiji https://www.intracen.org/ BB2016-03-08-WTO-Trade-Policy-Review-Fiji.

Investment Fiji. 2020a. Regional Trade Agreement, www.investmentfiji.org.fj.

Investment Fiji. 2020b. Mining \& Groundwater. https://www.investmentfiji.org.fj/pages.cfm/for-investors/ sector-industry-profiles/mining-groundwater.html

Krugman, R. 1984. Import Protection as Export Promotion: International Competition in the Presence of Oligopoly and Economies of Scale. In Monopolistic Competition and International Trade, ed. H. Kierzkowski, 180-193. Oxford: Oxford University Press.

Krugman, P. 1994. The Myth of Asia's Miracle. Foreign Affairs November/December.

Kumar, S. 2009. Estimating Export Equations for Developing Countries. The ICFAI University Journal of Applied Economics 8 (2): 17-28.

Kumar, S. 2014. Demand for Money in Developing Countries: Alternative Estimates and Policy Implications, 2014. Incorporated: Nova Science Publishers.

Leamer, E. 1983. Let's Take the Con Out of Econometrics. The America Economic Review 73 (1): 31-43.

Marian, B. and E. Milne. 1987. Export Diversification in Developing Countries: Recent Trends and Policy Impact. In Staff Studies for the World Economic Outlook, August, ed. International Monetary Fund.

Michaely, M. 1977. Exports and Economic Growth: An Empirical Investigation. Journal of Development Economics 4 (1): 49-53.

Ministry of Sugar. 2020. https://www.sugar.gov.fj/

MOE. 2020. Budget Estimate 2020-2021. Ministry of Economy, Fiji Islands.

Narayan, P., and S. Narayan. 2004. Determinants of Demand for Fiji's Exports: AN Empirical Estimation. The Developing Economies 42 (1): 95-112.

Narayan, P., and B. Prasad. 2003. Fiji's Sugar, Tourism and Garment Industries: A Survey of Performances, Problems and Potentials. Fijian Studies 1 (1): 1-26.

Ohlin, B. 1933. Interregional and International Trade. Cambridge: Harvard University Press.

Oum, S. and R. Singh. 2019. The Updated Input-Output Table for Fiji, Working Paper, School of Economics. https://www.usp.ac.fj/index.php?id=22922.

Pacific Community. 2017. Establishing and Implementing a Farmer Field School: A Handbook for Fiji's Sugar Cane Industry. SPC'S Suva Regional Office, Suva, Fiji.

Pacific Community. 2020. Visitor arrival numbers slump in the Pacific Island Countries and Territories. SPC'S Suva Regional Office, Suva, Fiji.

Paul, S. 2020. Macroeconomic Trends, Vulnerability and Resilience Capability in Small Island Developing States. In Shaping the Future of Small Islands Roadmap for Sustainable Development, ed. J.L. Roberts, S. Nath, S. Paul, and Y.N. Madhoo. Singapore: Palgrave Macmillan.

Phillip, P., and B. Hansen. 1990. Statistical Inference in Instrumental Variables Regression with I (1) Processes. Review of Economic Studies 57 (1): 99-125.

Prakash, K., and D. Maiti. 2016. Devaluation, Trade Balances and the J-Curve Phenomenon: The Case of Fiji. Economic Modelling 55 (June): 382-393.

Prasad, B.C., and C. Tisdell. 1996. Getting Property Rights 'Right': Land Tenure in Fiji. Pacific Economic Bulletin 11 (1): 31-48.

Prasad, S. 2000. Determinants of exports in Fiji. RBF Working Paper No. 2000/04, Reserve Bank of Fiji, Suva. 
Pratt, S. 2014. A General Equilibrium Analysis of the Economic Impact of a Devaluation on Tourism: The Case of Fiji. Tourism Economics 20 (2): 389-405. https://doi.org/10.5367/te.2013.0274.

Raj, S., and P. Chand. 2017. Analysis of Fiji's Export and Its Impact on Economic Growth. International Journal of Business and Social Research 7 (3): 1-14.

Ram, Y. and B. Prasad. 2007. Assessing Fiji's Global Trade Potential Using the Gravity Model Approach. School of Economics, the University of the South Pacific, Suva, Fiji.

Rao, B., and R. Singh. 2007. Estimating Export Equations. Applied Economics Letters 14 (11): 799-802.

Rao, B.B. and G. Rao. 2005a. Is the Gasoline Price Adjustment Equation for Fiji Asymmetric?. Working Paper No. Methodological Issues May-2005a 29 2005a/10, Department of Economics, the University of the South Pacific.

Rao, B.B. and G. Rao. 2005b. Further Evidence on Asymmetric US Gasoline Price Responses. Working Paper No. 2005b/11, Department of Economics, the University of the South Pacific.

Reserve Bank of Fiji. 2020. Quarterly Review. Suva: Reserve Bank of Fiji.

Reserve Bank of Fiji. 2019. Quarterly Review. Suva: Reserve Bank of Fiji.

Reddy, M. 1997. Devaluation and Economic Simulation: The Fiji Economy Post-coup. Pacific Economic Bulletin 12 (2): 85-94.

Sami, J. 2020. Time Series Dynamics of Sugar Export Earnings in Fiji with Multiple Endogenous Structural Breaks: Implications for EU Sugar and Industry Reforms. Journal of Quantitative Economics 18: 169-189. https://doi.org/10.1007/s40953-019-00173-z.

Sarin, V., S.K. Mahapatra, and N. Sood. 2020. Export Diversification and Economic Growth: A Review and Future Research Agenda. Journal of Public Affairs. https://doi.org/10.1002/pa.2524.

Schumpeter, J. 1942. Capitalism, Socialism, and Democracy. New York: Harper and Brothers.

Senhadji, A. and M. Claudio. 1998. Time Series Analysis of Export Demand Equations: A Cross-Country Analysis. IMF Working Paper 98/149 (Washington: International Monetary Fund).

Senhadji, A. 2000. Sources of Economic Growth: An Extensive Growth Accounting Exercise. IMF Staff Papers, No 47/1, International Monetary Fund, Washington DC, (USA).

Sharma, S., M. Norris, and D. Cheung. 1991. Exports and Economic Growth in Industrialising Countries. Applied Economics 26 (2): 45-51.

Singh, R. 2015. Forces of Economic Growth in China, India, and Other Asian Countries. Asian Pacific Economic Literature 29 (1): 62-81.

Singh, R., S. Lal, M. Khan, A. Patel, R. Chand, and D. Jain. 2021. The COVID-19 Experience in the Fiji Islands: Some Lessons for Crisis Management for Small Island Developing States of the Pacific Region and Beyond. New Zealand Economic Papers, TBC. pp. 1-6. ISSN 0077-9954.

Tinbergen, J. 1962. Shaping the World Economy: Suggestions for an International Economic Policy. New York: The Twentieth Century Fund.

Tisdell, C. 2014. The MIRAB Model of Small Island Economies in the Pacific and their Security Issues: Revised Version. Social Economics, Policy and Development Working Papers 165087, University of Queensland.

Tröster, B., and K. Küblböck. 2020. Unprecedented But Not Unpredictable: Effects of the COVID-19 Crisis on Commodity-Dependent Countries. The European Journal of Development Research 32: 1430-1449.

Udoidem, J., M. Emmanuel, and A. Etenam. 2017. Free Trade, Export Expansion and Economic Growth in Nigeria. Journal of Economics and Finance 8 (2): 2321-5933.

World Trade Organization. 2020. Regional Trade Agreements. https://www.wto.org/english/tratop_e/ region_e/region_e.htm.

World Development Report. 2020. Trade and Development in the Age of Global Value Chain. Washington DC: World Bank Group.

Publisher's Note Springer Nature remains neutral with regard to jurisdictional claims in published maps and institutional affiliations. 